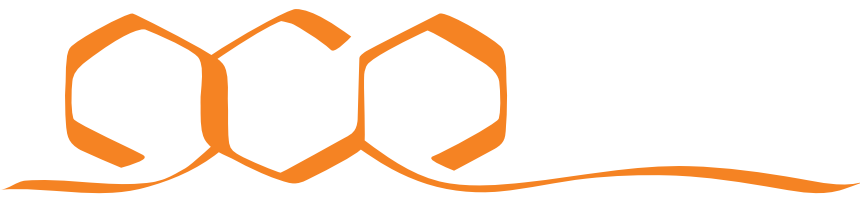 COMMUNICATIONS CHEMISTRY
}

\section{Author Correction: Positive functional synergy of structurally integrated artificial protein dimers assembled by Click chemistry}

\author{
Harley L. Worthy ${ }^{1,6}$, Husam Sabah Auhim ${ }^{1,2,6}$, W. David Jamieson ${ }^{3,6}$, Jacob R. Pope , Aaron Wall ${ }^{1,4}$, \\ Robert Batchelor ${ }^{1}$, Rachel L. Johnson ${ }^{1}$, Daniel W. Watkins ${ }^{1,5}$, Pierre Rizkallah (1) ${ }^{4}$, Oliver K. Castell ${ }^{3}$ \& \\ D. Dafydd Jones (i) ${ }^{1}$
}

Correction to: Communications Chemistry https:/doi.org/10.1038/s42004-019-0185-5, published online 19 July 2019.

The previously published version of this Article contained a consequential error in the fourth sentence of the "Discussion", which incorrectly read 'The use of the azF-SCO crosslink proved important as classical disulfide crosslinking did improve protein function'. The correct version states 'The use of the azF-SCO crosslink proved important as classical disulfide crosslinking did not improve protein function' - the word 'not' has been added as the 14th word. This has been corrected in both the PDF and HTML versions of the Article.

Published online: 20 August 2019

\begin{abstract}
(c) Open Access This article is licensed under a Creative Commons Attribution 4.0 International License, which permits use, sharing, adaptation, distribution and reproduction in any medium or format, as long as you give appropriate credit to the original author(s) and the source, provide a link to the Creative Commons license, and indicate if changes were made. The images or other third party material in this article are included in the article's Creative Commons license, unless indicated otherwise in a credit line to the material. If material is not included in the article's Creative Commons license and your intended use is not permitted by statutory regulation or exceeds the permitted use, you will need to obtain permission directly from the copyright holder. To view a copy of this license, visit http://creativecommons.org/licenses/by/4.0/.
\end{abstract}

(C) The Author(s) 2019

\footnotetext{
${ }^{1}$ Molecular Biosciences, School of Biosciences, Cardiff University, Cardiff, UK. ${ }^{2}$ Department of Biology, College of Science, Baghdad University, Baghdad, Iraq ${ }^{3}$ School of Pharmacy and Pharmaceutical Sciences, Cardiff University, Cardiff, UK. ${ }^{4}$ School of Medicine, Cardiff University, Cardiff, UK. ${ }^{5}$ Present address: School of Biochemistry, University of Bristol, Bristol, UK. ${ }^{6}$ These authors contributed equally: Harley L. Worthy, Husam Sabah Auhim, W. David Jamieson. Correspondence and requests for materials should be addressed to D.D.J. (email: jonesdd@cardiff.ac.uk)
} 